\title{
Selective Separation of Fluorite, Barite and Calcite with Valonea Extract and Sodium Fluosilicate as Depressants
}

\author{
Zijie Ren ${ }^{1, *}$, Futao Yu ${ }^{2}$, Huimin Gao ${ }^{1}$, Zhijie Chen ${ }^{1}$, Yongjun Peng ${ }^{3}$ and Lingyun Liu ${ }^{4}$ \\ 1 School of Resources and Environment Engineering, Wuhan University of Technology, Wuhan 430070, China; \\ gaohuimin1958@126.com (H.G.); czjczj@whut.edu.cn (Z.C.) \\ 2 Sichuan Province Bureau of Geology and Mineral Resources Exploration and Development Chengdu \\ Integrated Testing Center of Rocks and Ores, Chengdu 610084, China; yufutao926@163.com \\ 3 School of Chemical Engineering, The University of Queensland, St. Lucia, Brisbane, QLD 4072, Australia; \\ yongjun.peng@uq.edu.au \\ 4 School of Materials Science and Engineering, Anhui University of Science and Technology, Huainan 232001, \\ China; lyunliu@163.com \\ * Correspondence: renzijie@whut.edu.cn; Tel.: +86-027-8788-2128
}

Academic Editor: William Skinner

Received: 20 December 2016; Accepted: 9 February 2017; Published: 16 February 2017

\begin{abstract}
Fluorite, barite and calcite are important industry minerals. However, they often co-exist, presenting difficulty in selectively separating them due to their similar surface properties. In this study, valonea extract and sodium fluosilicate were used as depressants to selectively separate them by flotation, with sodium oleate as the collector. The single mineral flotation results showed that valonea extract displayed the strongest depression on calcite, while sodium fluosilicate displayed the strongest depression on barite. These two depressants allowed selective separation of the three minerals through sequential flotation. The flotation of mixed minerals showed that $94 \%$ of the calcite was successfully depressed by the valonea extract, and $95 \%$ recovery of the fluorite was achieved in the subsequent flotation with sodium fluosilicate depressing barite. The different depressant-mineral interactions were investigated via electro-kinetic studies and molecular dynamics (MD) simulations using the Materials Studio 6.0 program. The valonea extract exhibited the strongest adsorption on the calcite surface, and sodium fluosilicate exhibited the strongest adsorption on the barite surface, which prevented oleate species from reacting with $\mathrm{Ca}^{2+} \mathrm{Or} \mathrm{Ba}^{2+}$ surface sites. This study provides useful guidance for how to process fluorite, barite and calcite resources.
\end{abstract}

Keywords: fluorite; barite; calcite; valonea extract; sodium fluosilicate

\section{Introduction}

There are more than 30 million tons of fluorite and 25 million tons of barite resources in the Wulin Mountain area of China. Among them, about $90 \%$ of the fluorite is associated with barite, and the proportion of fluorite and barite in the ore is approximately $90 \%$. Other impurity minerals consist of mainly calcite and silicate [1]. Large quantities of this type of ore exist in other places throughout the world. However, flotation separation of fluorite, barite and calcite is difficult, due to their similar surface properties and narrow differences in floatability [2].

Calcite and fluorite can be separated by the adsorption-washing-flotation method using sodium dodecyl sulphate as collector [3]. The acid-grade fluorite concentrates can be obtained with oleoylsarcosine as a collector and quebracho depressant at $\mathrm{pH}$ 8-9 from ores containing more than $6 \%$ calcite [4]. Giesekke and Harris found that fluorite could be floated using a single bubble-stream 
microflotation cell with sodium oleate as the collector and wattle-bark extract as the depressant [5]. However, these methods are not suitable for ores containing barite.

Many researchers have come to the consensus that selecting the proper depressant is crucial for the selective flotation recovery of these three minerals [2]. Depressants, such as acidized sodium silicate [6,7], modified sodium silicate [8] and sodium hexametaphosphate with salified sodium silicate [9], have been used to depress calcite. Sodium silicate, sodium hexametaphosphate, sodium fluosilicate [10], dextrin [11,12] and aluminium sulphate [13] have been used to depress barite. However, a systematic study on the effects of depressants on the flotability of fluorite, barite and calcite has not been reported in the literature, and an efficient depressant for the selective flotation separation of these three minerals is still unavailable.

The objective of this study is to investigate the effects of valonea extract and sodium fluosilicate on the flotation separation of fluorite, barite and calcite. The mechanism of the selective separation was investigated through zeta potential measurements. The results are discussed using a molecular dynamics (MD) simulation to verify experimental results using theoretical computations.

\section{Materials and Methods}

\subsection{Pure Minerals and Reagents}

Pure fluorite, barite and calcite were from Chongqing, China. Their chemical compositions were determined using an X-ray fluorescence spectrometer (XRF) (Axios advanced, PANalytical B.V., Almelo, The Netherlands) and are summarized in Table 1.

Table 1. Chemical composition of the pure fluorite, barite and calcite (\%).

\begin{tabular}{cccccccccccccc}
\hline Component & $\mathbf{S O}_{3}$ & $\mathrm{CaO}$ & $\mathbf{C l}$ & $\mathbf{B a O}$ & $\mathbf{M g O}$ & $\mathrm{Al}_{2} \mathbf{O}_{3}$ & $\mathbf{S i O}_{2}$ & $\mathbf{S r O}$ & $\mathbf{F}$ & $\mathbf{N a}_{2} \mathbf{O}$ & $\mathbf{C s}_{2} \mathbf{O}$ & $\mathbf{I}$ & L.O.L. $^{\mathbf{a}}$ \\
\hline Fluorite & 0.23 & 51.18 & 0.02 & 0.37 & 0.03 & - & 0.10 & 0.02 & 47.44 & - & - & - & 0.63 \\
Barite & 31.69 & 1.50 & 0.02 & 65.15 & - & 0.17 & - & - & - & 0.44 & 0.82 & - & 0.20 \\
Calcite & 0.51 & 54.90 & 0.02 & 1.34 & 0.21 & 0.01 & 0.02 & 0.09 & - & - & - & 0.02 & 42.90 \\
\hline \multicolumn{10}{c}{}
\end{tabular}

As shown in Table 1, the $\mathrm{CaF}_{2}$ content of fluorite was $97.25 \%$; the $\mathrm{BaSO}_{4}$ content of barite was $97.02 \%$; and the $\mathrm{CaCO}_{3}$ content of calcite was $97.50 \%$. The $-150 \mu \mathrm{m}+74 \mu \mathrm{m}$ fraction was used in the flotation tests. The $-74 \mu \mathrm{m}$ fraction was removed in the case of fine particle entrainment. Some samples were further ground to $-10 \mu \mathrm{m}$ in an agate mortar and were used for zeta potential measurements. The mixed minerals were obtained by blending the pure fluorite, barite and calcite with a mass ratio of 45:45:10.

The chemical reagents used in this study included: analytical-grade sodium carbonate $\left(\mathrm{Na}_{2} \mathrm{CO}_{3}\right.$, Hongguang Chemical Factory, Shanghai, China) and analytical-grade sulfuric acid $\left(\mathrm{H}_{2} \mathrm{SO}_{4}\right.$, Dongda Chemical Co., Ltd., Kaifeng, China) for $\mathrm{pH}$ adjustment; analytical-grade hydrochloric acid ( $\mathrm{HCl}$, Xinyang, China) for the analysis of calcite content; analytical-grade sodium oleate as the collector and boric acid $\left(\mathrm{H}_{3} \mathrm{BO}_{3}\right.$, Chinese medicine group chemical reagent Co., Ltd., Shanghai, China) for the analysis of barite content; analytical-grade sodium fluosilicate (Zonghengxing Gongmao Co., Ltd., Tianjin, China); and technical-grade valonea extract from a valonea extract factory for depressants. Valonea extract was a polyphenol mixture that mainly consisted of different types of tannins [14]. The typical molecule structure of tannin in the valonea extract is shown in Figure 1.

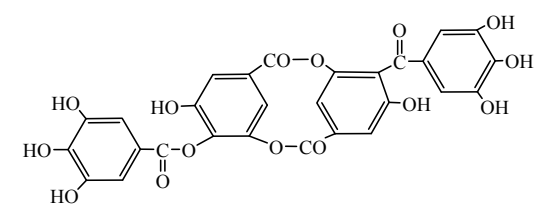

Figure 1. Typical molecule structure of tannin in valonea extract. 


\subsection{Flotation Experiment}

Single mineral flotation tests were carried out in an RK/FGC flotation machine (Wuhan rock grinding equipment manufacture Co., Ltd., Wuhan, China) with a 30-mL cell at an impeller speed of $1960 \mathrm{rpm}$. The mineral suspension was prepared by adding $2.0 \mathrm{~g}$ of minerals to $30 \mathrm{~mL}$ of solution with a certain $\mathrm{pH}$ value, which was first adjusted by adding $\mathrm{Na}_{2} \mathrm{CO}_{3}$ or $\mathrm{H}_{2} \mathrm{SO}_{4}$. After the flotation reagent was added, the suspension was agitated for $2 \mathrm{~min}$. The flotation lasted for $4 \mathrm{~min}$ before the products were collected, dried and weighed. The recovery was calculated based on the weight of the dried floating products divided by the feed solids.

The mixed mineral flotation tests were carried out in the same flotation machine with a 70-mL cell. The mineral suspension was prepared by adding $5.0 \mathrm{~g}$ of minerals to $70 \mathrm{~mL}$ of solution with a certain $\mathrm{pH}$ value. The agitation and flotation time were also $2 \mathrm{~min}$ and $4 \mathrm{~min}$, respectively. The calcite content of the flotation material was calculated after dissolving the material with concentrated hydrochloric acid. The barite content was obtained by dissolving fluorite with concentrated hydrochloric acid and $40 \mathrm{~g} / \mathrm{L}$ boric acid.

\subsection{Zeta Potential Measurement}

Before standing for $2 \mathrm{~h}$, mineral suspensions containing $0.1 \%$ solids and a given flotation reagent concentration were conditioned in an ultrasonic bath for $2 \mathrm{~min}$. The zeta potentials of the upper suspended solids at different $\mathrm{pH}$ values were conducted at $20^{\circ} \mathrm{C}$ using a 90 Plus Particle Size Analyzer (Brookhaven Instruments Corporation, Holtsville, NY, USA).

\subsection{Molecular Dynamics Simulations}

The calculations were performed in the framework of the MD, using the Material Studio 6.0 (MS) package. First, the Cambridge Sequential Total Energy Package (CASTEP) module included in the MS software was adopted to optimize the crystal structures of fluorite, barite and calcite. By comparing different parameters to be optimized, the best optimization parameters were as follows: a function was modified with Perdew-Burke-Ernzerhof generalized gradient approximation (PBEsol GGA); the $k$-point set was $3 \times 3 \times 4$; the self-consistent-field $(\mathrm{SCF})$ tolerance was $1.0 \times 10^{-6} \mathrm{eV} / \mathrm{atom}$; and the custom energy cut-off was $300 \mathrm{eV}$. The lattice optimization results are shown in Table 2. It is encouraging to note that the simulation agreed well with the experimental results analysed from X-ray experiments. Then, 2D periodic surface cells were created from the unit cells of fluorite, barite and calcite at the cleavage plane (111), (001) and (104), respectively. The optimized surface slab was extended to a periodic super lattice of approximately $20 \AA \times 20 \AA$ with a certain vacuum thickness of $30 \AA ̊[15]$.

Table 2. Comparison of the lattice parameters for fluorite, barite and calcite obtained from Density Functional Theory (DFT) calculations and XRD experiments.

\begin{tabular}{ccc}
\hline \multirow{2}{*}{ Minerals } & \multicolumn{2}{c}{ Lattice Parameters } \\
\cline { 2 - 3 } & Experimental & DFT Predicted \\
\hline \multirow{2}{*}{ Fluorite } & $\begin{array}{c}a=5.463 \AA, b=5.463 \AA, \\
c=5.463 \AA, \alpha=\beta=\gamma=90^{\circ}\end{array}$ & $\begin{array}{c}a=5.463 \AA, b=5.463 \AA, \\
c=5.463 \AA, \alpha=\beta=\gamma=90^{\circ}\end{array}$ \\
\hline \multirow{2}{*}{ Barite } & $a=8.881 \AA, b=5.454 \AA$, & $a=8.884 \AA, b=5.458 \AA$, \\
& $c=7.156 \AA, \alpha=\beta=\gamma=90^{\circ}$ & $c=7.153 \AA, \alpha=\beta=\gamma=90^{\circ}$ \\
\hline \multirow{2}{*}{ Calcite } & $a=4.989 \AA, b=4.989 \AA$, & $a=4.987 \AA, b=4.987 \AA$, \\
& $c=17.062 \AA, \alpha=\beta=90^{\circ}, \gamma=120^{\circ}$ & $c=17.051 \AA, \alpha=\beta=90^{\circ}, \gamma=120^{\circ}$ \\
\hline
\end{tabular}

Second, the tannin, sodium fluosilicate and water molecule were optimized using the DMol3 module. The optimization parameters are as follows: the quality was medium, and the functional 
was a local spin density approximation with the Perdew-Wang correlation (LDA/PWC). A symmetry calculation was performed.

Finally, the DISCOVER module was employed to calculate adsorption energies. Tannin, the main component of valonea extract, and sodium fluosilicate were used as adsorbates. The optimized adsorbate molecules were placed on the top mineral surface, while the bottom-most layers were kept frozen. The initial geometry of the mineral surface-adsorbate molecule complex was created with the help of molecular graphics tools. First, the geometry optimization of the system of reagent-mineral was conducted using a Smart Minimizer with the COMPASS force field [16], and the atom-based cut-off method was employed for calculating both the van der Waals and electrostatic interactions (Coulombic) [15]. The atom-based cut-offs were used with a $9.5 \AA$ cut-off distance, which was less than half of the length of the simulation cell $[15,17]$ with a spline width of $1.0 \AA$ and a buffer width of $0.5 \AA$. Because the configuration obtained with this method was only one of the possible adsorption modes, approximately 20 starting conformations were assessed in order to locate the minimum energy conformation of the molecule on the mineral surface. The most stable configuration of mineral surface-surfactant complex with the highest negative total energy was chosen for further MD simulations, and the coordinates of surface atoms were constrained during the MD simulations with the adsorbates being free [15].

In the current formulation, it was difficult to account for the effect of aqueous environments on mineral-reagent interactions [18]. Solvent (water) molecules were not included in the simulations, but the interaction energy of water molecules for each mineral surface was computed and compared with the corresponding adsorbate-mineral interaction energy [15].

MD simulations were conducted with the COMPASS force field. The settings were the same as the geometry optimization procedure. All simulations were performed at constant volume and temperature (NVT). The time step was $1.0 \mathrm{fs}$, and the total run length was $300 \mathrm{ps}$. Finally, the interaction energy was calculated using the following equation $[18,19]$ :

$$
E_{i}=E_{t}-\left(E_{m}+E_{r}\right)
$$

where $E_{t}, E_{m}$ and $E_{r}$ are the total energy of the optimized reagent-mineral complex, surface cluster and reagent molecule, respectively [17]. More negative magnitudes of interaction energy $\left(E_{i}\right)$ correspond to more favourable interactions between the mineral surface and the depressants. The magnitude of $E_{i}$ is thus an excellent measure of the relative efficiency of interaction of different collectors with minerals [20].

\section{Results and Discussions}

\subsection{Single Mineral Flotation}

\subsubsection{Effects of Sodium Oleate Dosage on Flotation Behaviour}

The fatty acid type collectors, such as oleic acid and sodium oleate, are widely used in the flotation of fluorite, barite and calcite [21-24]. Flotation recovery of these three minerals with different sodium oleate dosages at $\mathrm{pH}=7$ are presented in Figure 2. The flotation recovery of barite was the highest, and that of calcite was the lowest. Increasing collector dosage boosted flotation recovery of the three pure minerals. While the recovery of barite and fluorite was more than $90 \%$ at all levels of collector addition, a significant increase in the recovery of calcite was observed (from $50 \%$ to over $90 \%$ ), with increasing the sodium oleate dosage from $2 \times 10^{-5} \mathrm{~mol} / \mathrm{L}$ to $10 \times 10^{-5} \mathrm{~mol} / \mathrm{L}$. Thus, the lower concentration of sodium oleate benefited the removal of calcite from fluorite and barite, by keeping the calcite in the tailings.

The solubility products of fluorite and barite are $4 \times 10^{-11}$ and $1 \times 10^{-10}$, respectively, which are relatively low. Therefore, the dissolved Ca or Ba ions from the mineral surfaces in the pulp would be limited, and their effect on consuming the collector (sodium oleate) was minimal. Consequently, 
the added sodium oleate can easily form precipitates of calcium oleate or barium oleate on the mineral surfaces, rendering the mineral surface hydrophobic and contributing to enhanced flotation recovery. However, the solubility product of calcite is $1 \times 10^{-8}$, which is much higher than those of fluorite and barite. A large amount of $\mathrm{Ca}^{2+}$ dissolved from the calcite may react with the added sodium oleate to generate an insoluble substance in the pulp, which reduced the added available oleate ions adsorbing on, and enhancing the hydrophobicity of, the calcite. As a result, more sodium oleates were needed for improving the flotation recovery of calcite [24].

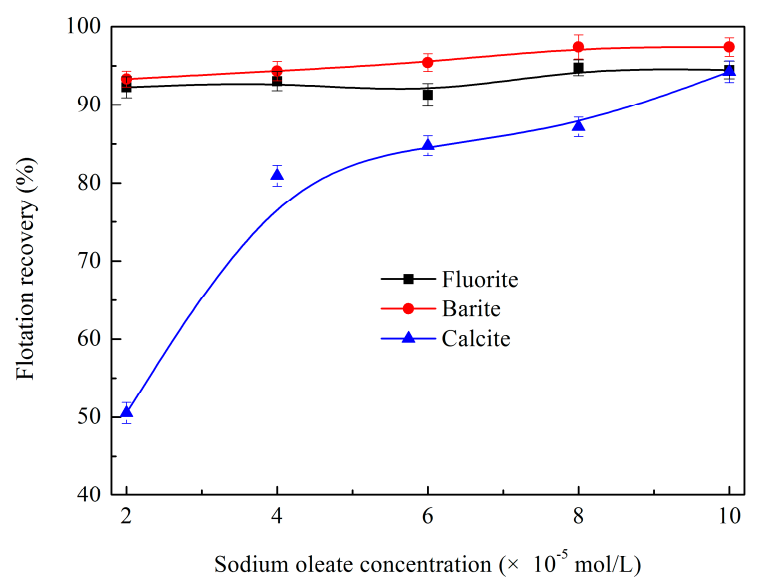

Figure 2. Effects of sodium oleate dosage on flotation recovery $(\mathrm{pH}=7)$.

\subsubsection{Effects of $\mathrm{pH}$ Value on Flotation Behaviour}

The flotation results at different $\mathrm{pH}$ values are given in Figure 3. The flotation recovery of calcite was lowest at $\mathrm{pH}=7$. For the fluorite, in the range of $6-9$, the flotation recoveries were over $90 \%$. That of barite at $\mathrm{pH}$ 6-7 was also higher than 90\%; however, there was no floated barite when the $\mathrm{pH}$ was 5 , because the IEPs (isoelectric points) of barite are located at $\mathrm{pH}$ 3.1. The flotation recoveries of fluorite and barite at $\mathrm{pH}=7$ were both more than $90 \%$, but that of calcite was about $80 \%$, which was beneficial to the removal of calcite from fluorite and barite.

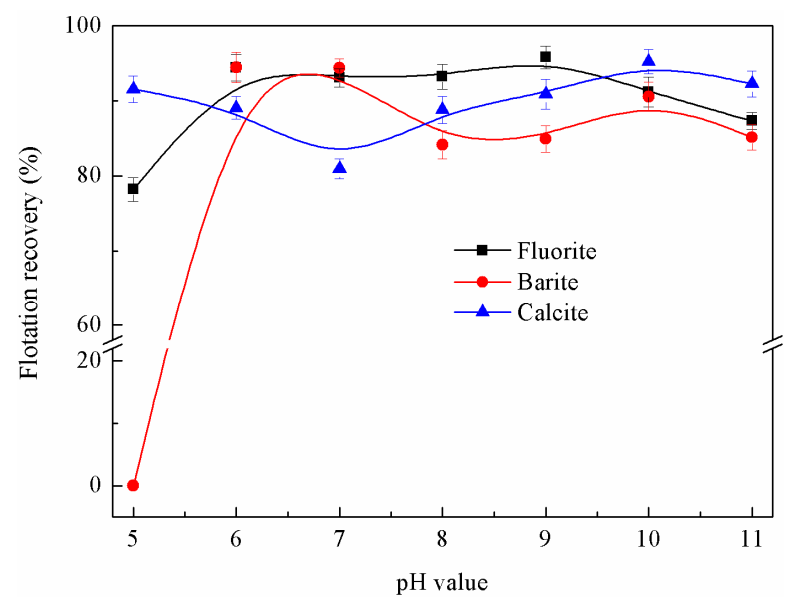

Figure 3. Effects of $\mathrm{pH}$ value on flotation recovery (sodium oleate dosage $=4 \times 10^{-5} \mathrm{~mol} / \mathrm{L}$ ).

\subsubsection{Effects of Valonea Extract Dosage on Flotation Behaviour}

The flotation recoveries of three minerals with valonea extract are shown in Figure 4 . With the increase in valonea extract dosage, the flotation recoveries of all three minerals decreased. Obviously, the depressing effect on calcite flotation was the strongest, and calcite was completely depressed at 
a dosage of more than $4 \times 10^{-4} \mathrm{~g} / \mathrm{L}$. Therefore, the separation of calcite with fluorite and barite can be achieved by floating fluorite and barite with the addition of more than $4 \times 10^{-4} \mathrm{~g} / \mathrm{L}$ valonea extract.

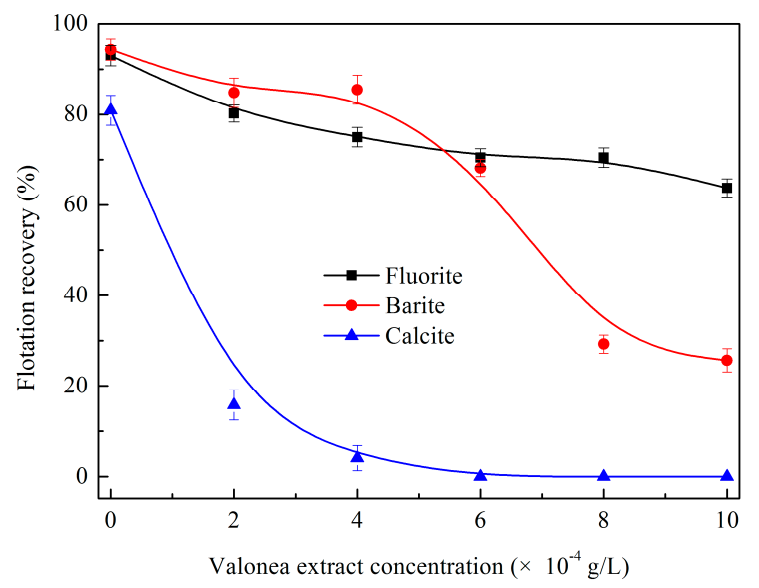

Figure 4. Effects of valonea extract dosage on flotation recovery (sodium oleate dosage $=4 \times 10^{-5} \mathrm{~mol} / \mathrm{L}$, $\mathrm{pH}=7)$.

\subsubsection{Effects of Sodium Fluosilicate Dosage on Flotation Behaviour}

The flotation recoveries of three minerals with sodium fluosilicate are given in Figure 5 . When the sodium fluosilicate concentration changed from 0 to $4 \times 10^{-5} \mathrm{~mol} / \mathrm{L}$, there were small variations in the flotation recoveries of fluorite and calcite, all of which were nearly higher than $80 \%$. However, the barite was strongly depressed when more than $2 \times 10^{-5} \mathrm{~mol} / \mathrm{L}$ sodium fluosilicate was present. When the sodium fluosilicate concentration was $4 \times 10^{-5} \mathrm{~mol} / \mathrm{L}$, no barite floated. As a result, the separation of barite from fluorite and calcite can be achieved by adding more than $3 \times 10^{-5} \mathrm{~mol} / \mathrm{L}$ sodium fluosilicate.

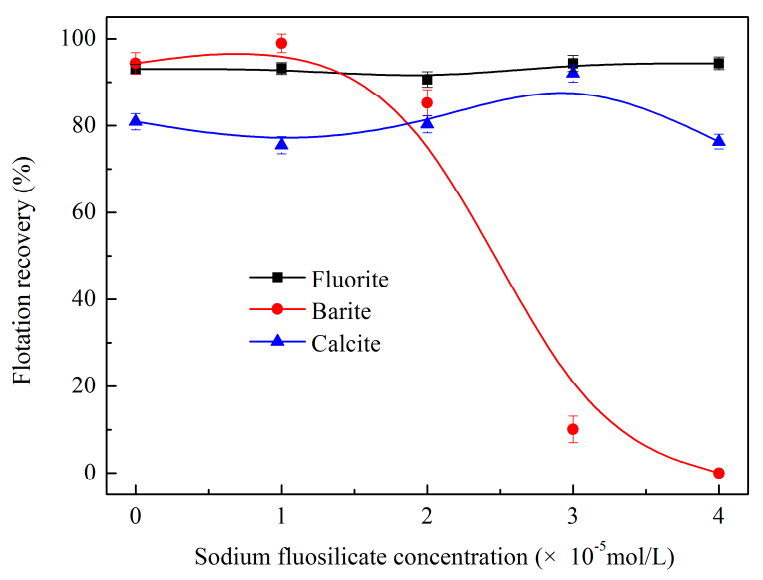

Figure 5. Effects of sodium fluosilicate dosage on flotation recovery (sodium oleate dosage $=4 \times 10^{-5}$ $\mathrm{mol} / \mathrm{L}, \mathrm{pH}=7)$.

Other studies reported in literature had similar conclusions. Yu found that with an increase in the sodium fluosilicate dosage, the flotation recoveries of fluorite and calcite remained nearly unchanged, which means that they could not be completely depressed by sodium fluosilicate [25]. In a study of evaluating the effects of sodium fluosilicate on the flotation of bastnasite, barite, fluorite and calcite, Wang found that the depressing effect on barite was the strongest [26].

Not only barite, but also silicate minerals could be markedly depressed by sodium fluosilicate $[27,28]$. In the flotation of rutile ore [29] and iron-ore tailings [30], sodium fluosilicate was used to depress 
silicate minerals. Thus, in the selective separation of fluorite, barite and calcite with sodium fluosilicate, the silicate minerals, such as quartz and feldspar, can also be depressed.

\subsection{Flotation Experiment of Mixed Minerals}

According to the above results, these three minerals in the mixture could be separated by flotation, as described in the flowsheet (Figure 6): bulk floating fluorite and barite by depressing calcite and then floating the fluorite in the collected froth product by depressing the barite. The flotation results are summarized in Table 3.

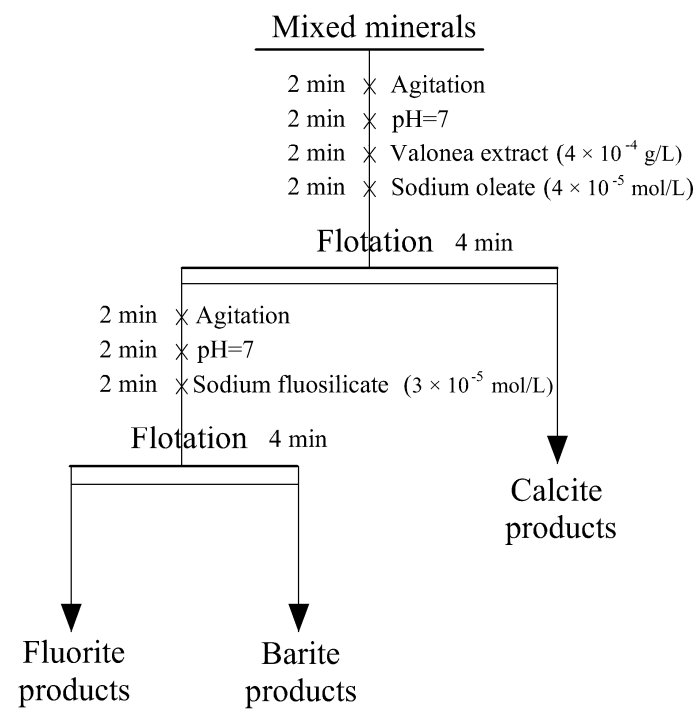

Figure 6. Flotation flowsheet of selective separation.

Table 3. Experimental results of mixed minerals' flotation.

\begin{tabular}{cccccccc}
\hline \multirow{2}{*}{ Samples } & \multirow{2}{*}{ Yield (\%) } & \multicolumn{3}{c}{ Grade (\%) } & \multicolumn{3}{c}{ Recovery (\%) } \\
\cline { 3 - 8 } & & $\mathrm{CaCO}_{\mathbf{3}}$ & $\mathbf{C a F}_{\mathbf{2}}$ & $\mathbf{B a S O}_{\mathbf{4}}$ & $\mathrm{CaCO}_{\mathbf{3}}$ & $\mathbf{C a F}_{\mathbf{2}}$ & $\mathbf{B a S O}_{\mathbf{4}}$ \\
\hline Calcite products & 28.21 & 33.26 & 42.03 & 24.71 & 93.83 & 26.35 & 15.49 \\
Fluorite products & 32.36 & 1.66 & 94.71 & 3.63 & 5.38 & 68.10 & 2.61 \\
Barite products & 39.43 & 0.20 & 6.33 & 93.47 & 0.79 & 5.55 & 81.90 \\
Mixed minerals & 100.00 & 10.00 & 45.00 & 45.00 & 100.00 & 100.00 & 100.00 \\
\hline
\end{tabular}

As shown in Table 3, after bulk flotation of fluorite and barite with valonea extract to depress calcite, $93.83 \%$ of the calcite remained in the tailing. Obviously, the depressing effect to calcite by valonea extract in the bulk flotation was striking. The content of $\mathrm{CaF}_{2}$ and $\mathrm{BaSO}_{4}$ in the calcite product was $42.03 \%$ and $24.71 \%$, respectively. This was attributed to the fact that fluorite and barite could also be depressed slightly by valonea extract (Figure 4), but they could be reduced by several stages of scavenging the flotation tailings. At the same time, the recovery of fluorite and barite could be further increased after the scavenged concentrate was recycled.

The obtained froth product was further processed to float fluorite while depressing barite, by adding sodium fluosilicate. The $\mathrm{CaF}_{2}$ grade of the fluorite product reached $94.71 \%$. While the $\mathrm{CaCO}_{3}$ recovery to the fluorite product was $5.38 \%$ (i.e., to the froth), its recovery to the barite product was only $0.79 \%$ (i.e., to the tailings). In other words, most calcite minerals appearing in the froth after the bulk flotation were also re-floated to the froth. This finding can be explained by the fact that when the sodium fluosilicate concentration was $3 \times 10^{-5} \mathrm{~mol} / \mathrm{L}$, approximately $90 \%$ of the calcite responded to flotation (Figure 5). The collected fluorite product will be able to meet the standard of acid-grade fluorite $\left(\mathrm{CaF}_{2}\right.$ grade $\left.>97 \%\right)$ after several stages of cleaning with valonea extract to depress the calcite and sodium fluosilicate to depress the barite. 
The $\mathrm{BaSO}_{4}$ grade of the barite product was $93.47 \%$, and it can be used as a heavy loader for directly drilling. A higher quality barite product for the chemical industry can be obtained after a few stages of scavenging flotation.

\subsection{Zeta Potential Measurement Results}

In this study, the zeta potentials of fluorite, calcite and barite minerals in the absence and presence of sodium fluosilicate or valonea extract were measured. As plotted in Figures 7-9, in the absence of any reagent, IEPs of fluorite, calcite and barite are located at $\mathrm{pH} 6.4, \mathrm{pH} 5.3$ and $\mathrm{pH} 3.1$, respectively, in agreement with the literature data [24].
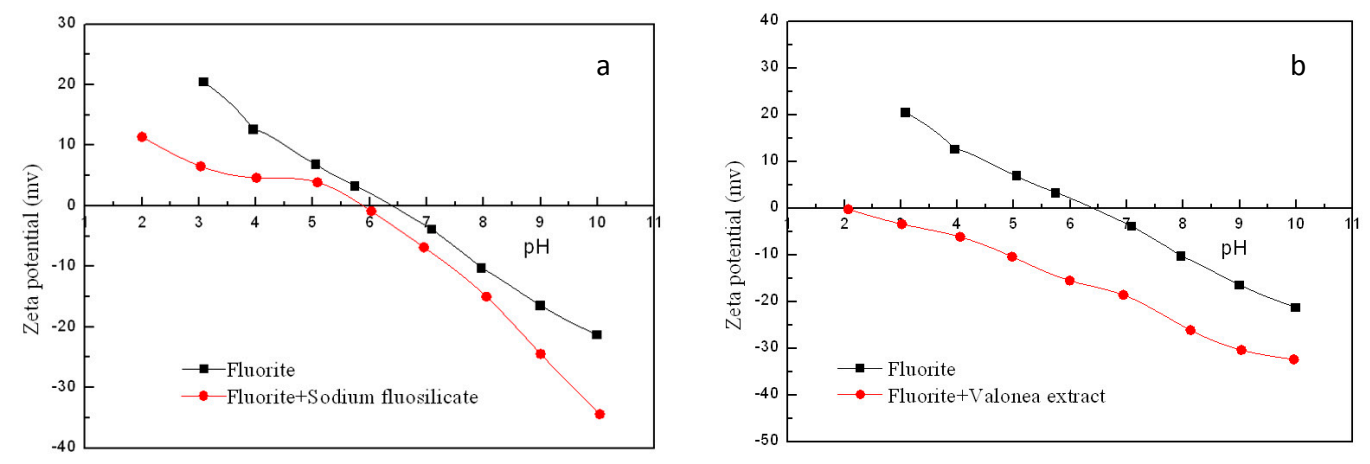

Figure 7. Effect of the addition of sodium fluosilicate (a) and valonea extract (b) on the zeta potential of fluorite (sodium fluosilicate dosage $=3 \times 10^{-5} \mathrm{~mol} / \mathrm{L}$, valonea extract dosage $=4 \times 10^{-4} \mathrm{~g} / \mathrm{L}$ ) .
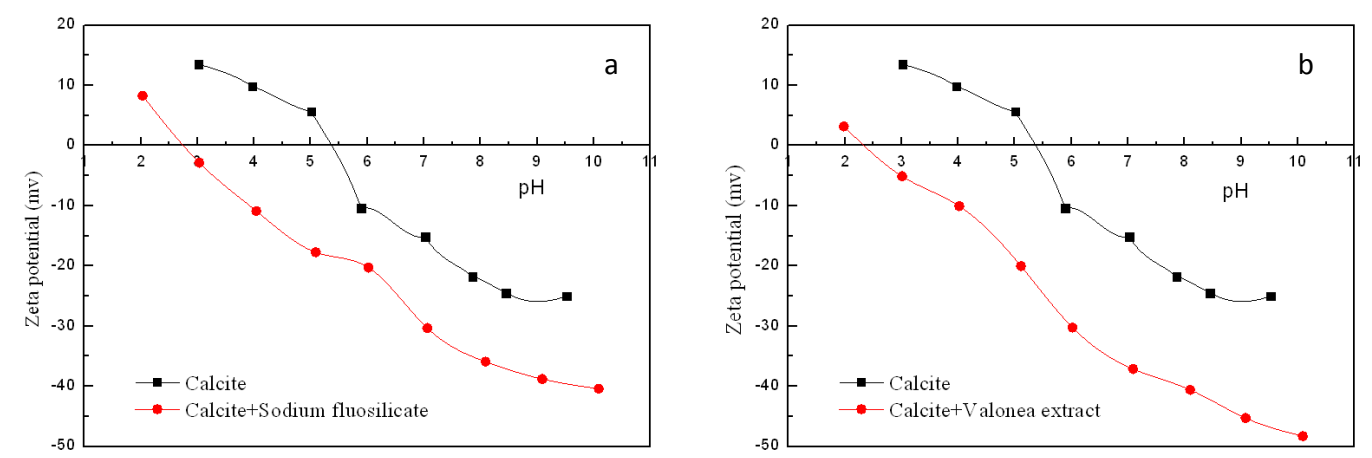

Figure 8. Effect of addition of sodium fluosilicate (a) and valonea extract (b) on the zeta potential of calcite (sodium fluosilicate dosage $=3 \times 10^{-5} \mathrm{~mol} / \mathrm{L}$, valonea extract dosage $=4 \times 10^{-4} \mathrm{~g} / \mathrm{L}$ ) .
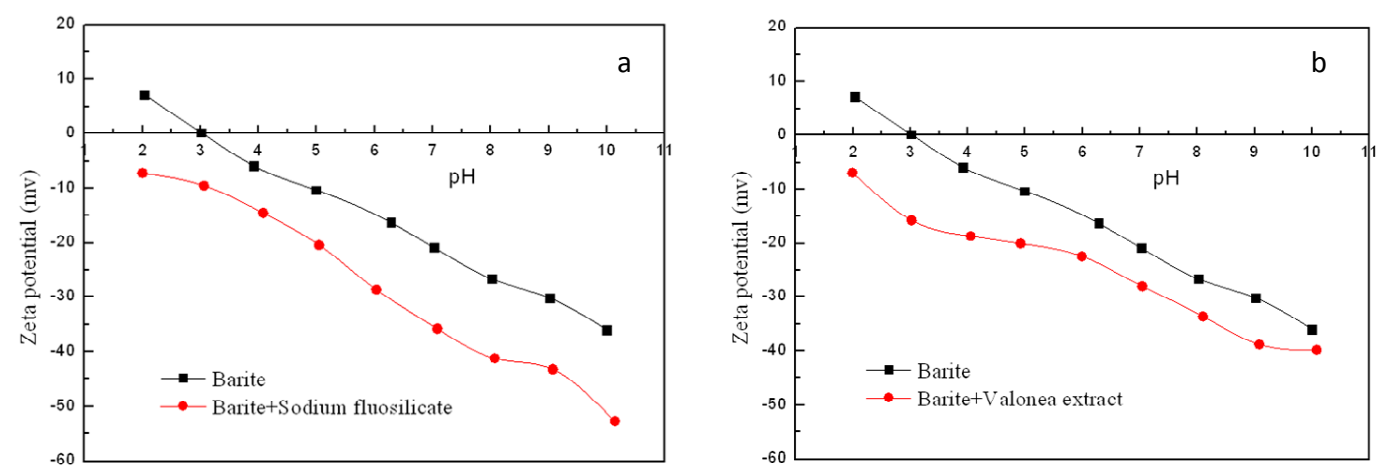

Figure 9. Effect of addition of sodium fluosilicate (a) and valonea extract (b) on the zeta potential of barite (sodium fluosilicate dosage $=3 \times 10^{-5} \mathrm{~mol} / \mathrm{L}$, valonea extract dosage $=4 \times 10^{-4} \mathrm{~g} / \mathrm{L}$ ). 
After adding depressants, zeta potentials of the three tested minerals became more negatively charged, suggesting their adsorption on the mineral surfaces to change the surface potentials. As shown in Figure 1, the tannin was negatively charged when ionized. The ionization and hydrolysis of sodium fluosilicate were as follows [31]:

$$
\begin{aligned}
\mathrm{Na}_{2} \mathrm{SiF}_{6} & =2 \mathrm{Na}^{+}+\mathrm{SiF}_{6}{ }^{2-} \\
\mathrm{SiF}_{6}{ }^{2-}+3 \mathrm{H}_{2} \mathrm{O} & =4 \mathrm{H}^{+}+6 \mathrm{~F}^{-}+\mathrm{H}_{2} \mathrm{SiO}_{3}
\end{aligned}
$$

With the breakage of fluorite, barite or calcite crystals, $\mathrm{Ca}^{2+}$ or $\mathrm{Ba}^{2+}$ was exposed on the mineral surfaces [26]. Consequently, the (absolute) value of the zeta potential decreased after the adsorption of negatively-charged tannin or $\mathrm{SiF}_{6}{ }^{2-}$ or $\mathrm{F}^{-}$to the positive metallic site of the mineral surface, forming surface precipitates of $\mathrm{CaSiF}_{6}$ and $\mathrm{BaSiF}_{6}$ or $\mathrm{CaF}_{2}$ and $\mathrm{BaF}_{2}$.

Figure 7 shows that in the range of $\mathrm{pH} 6-9$, the addition of sodium fluosilicate and valonea extract causes a decrease in (absolute) zeta potential of fluorite by $4-8 \mathrm{mV}$ and approximately $15 \mathrm{mV}$, respectively, suggesting a much stronger adsorption and reaction of valonea extract than sodium fluosilicate on the mineral surface. As a result, less oleate, which was also negatively charged, was adsorbed on the mineral surface, leading to less hydrophobicity of the solids in the presence of valonea extract. This finding matched well with the flotation results shown in Figures 4 and 5, where fluorite recovery was higher in the presence of sodium fluosilicate than that of valonea extract, at the same pulp $\mathrm{pH}$.

As plotted in Figure 8, the addition of sodium fluosilicate or valonea extract causes (absolute) zeta potential reduction for calcite minerals at $\mathrm{pH}$ 6-9, with a severer decrease in (absolute) zeta potential by valonea extract. The obtained results could explain why the calcite recovery was depressed by adding valonea extract (Figure 4). On the other hand, in the same $\mathrm{pH}$ range, the addition of sodium fluosilicate causes a larger reduction in the (absolute) zeta potential of barite minerals (Figure 9) than the addition of valonea extract. Based on the trend in Figure 8, a higher barite recovery would be expected in the presence of valonea extract than that in the presence of sodium fluosilicate, which was the case as shown in Figures 4 and 5.

\subsection{Computation of Interaction Energy by MD Simulations}

MD simulations are able to describe the crystal structure specificity of depressant molecules with different minerals. The computed interaction energies of tannin and sodium fluosilicate molecules with fluorite (111), barite (001) and calcite (104) surfaces are compared in Table 4, and the final adsorption configurations of depressants with minerals are shown in Figure 10.

Table 4. A comparison of computed interaction energies $(\mathrm{kcal} / \mathrm{mol})$ of adsorbate molecules on mineral surfaces.

\begin{tabular}{cccc}
\hline \multirow{2}{*}{ Adsorbate } & \multicolumn{3}{c}{ Adsorbent } \\
\cline { 2 - 4 } & Fluorite & Barite & Calcite \\
\hline Tannin & -897.38 & -1910.45 & -3169.39 \\
Sodium fluosilicate & -81.74 & -92.46 & -86.24 \\
Water & -16.34 & -21.24 & -31.12 \\
\hline
\end{tabular}




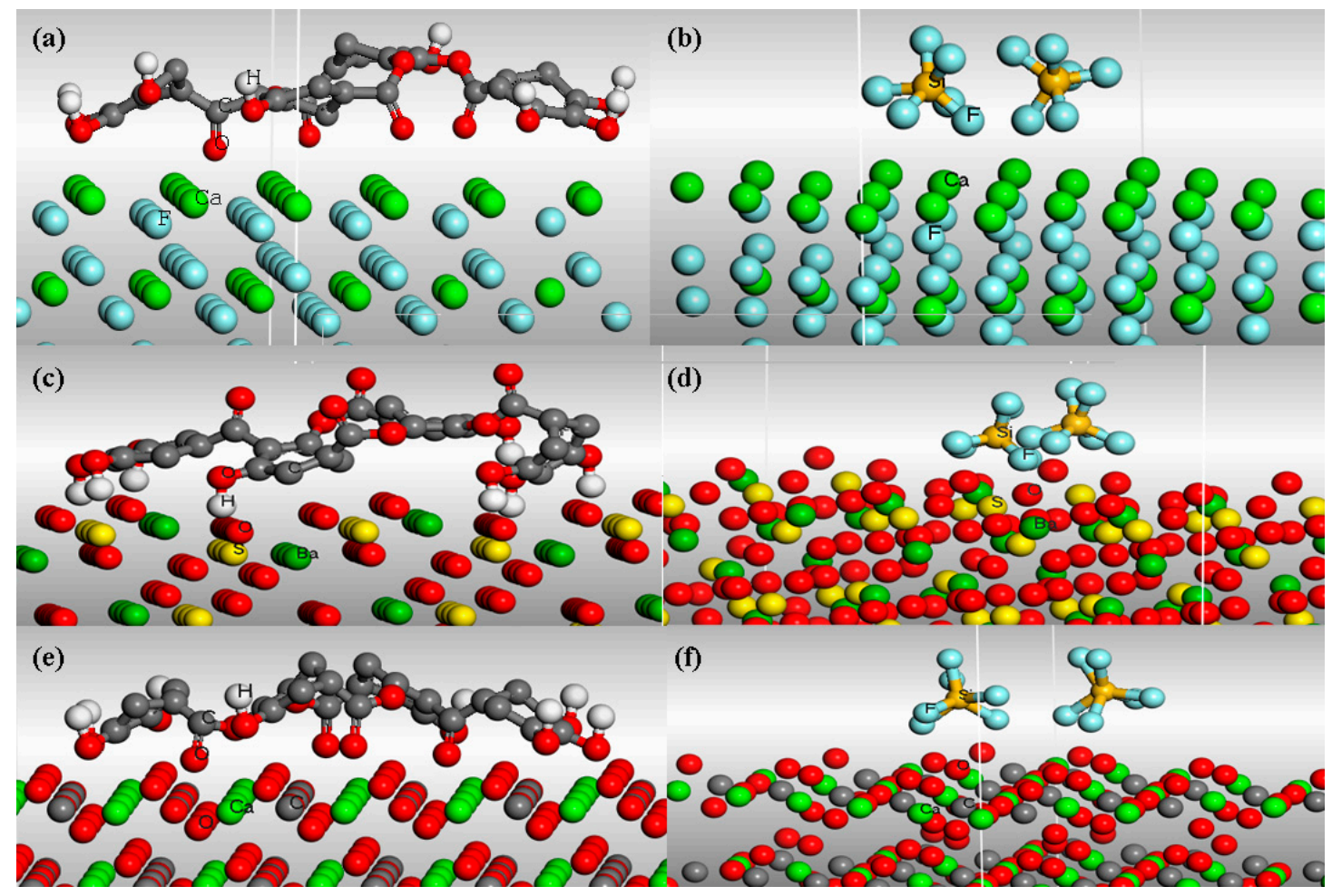

Figure 10. The optimized adsorption models of depressants on mineral surface: (a) tannin on fluorite surface; (b) sodium fluosilicate on fluorite surface; (c) tannin on barite surface; (d) sodium fluosilicate on barite surface; (e) tannin on calcite surface; (f) sodium fluosilicate on calcite surface.

As illustrated in Table 4, the interaction energies of the water molecules with mineral surfaces are much smaller than those of the depressants, confirming that the depressants indeed adsorb on the mineral surfaces by replacing water. The magnitude of tannin adsorption energies on mineral surfaces is in the order of: calcite > barite > fluorite; and that of sodium fluosilicate adsorption energies is in the order of: barite $>$ calcite $>$ fluorite. Such trends are consistent with the flotation results (Figures 4 and 5), i.e., the order of flotation recovery with the addition of tannin is: calcite < barite < fluorite; and barite $<$ calcite $<$ fluorite with the addition of sodium fluosilicate. The MD simulations results match well with the experimental results.

It is noted from Table 4 that the tannin molecule adsorption energy is the highest on the calcite surface and that the sodium fluosilicate molecule adsorption is the highest on the barite surface. Such a strong adsorption of depressants on the mineral surfaces prevents the oleate species from reacting with the $\mathrm{Ca}^{2+}$ or $\mathrm{Ba}^{2+}$ surface sites. Consequently, the depressing effect of valonea extract on calcite was the strongest, and the depressing effect of sodium fluosilicate on barite was the strongest.

\section{Conclusions}

The separation of calcite from fluorite and barite in a mixed mineral pulp can be achieved by floating fluorite and barite, with $>4 \times 10^{-4} \mathrm{~g} / \mathrm{L}$ valonea extract to depress calcite flotation, leaving the calcite in the tailings. The separation of barite from fluorite (and calcite) can be realized by adding $>3 \times 10^{-5} \mathrm{~mol} / \mathrm{L}$ sodium fluosilicate to depress the barite and to float fluorite. This developed flotation separation process exhibits a great potential for industrial application.

The valonea extract and sodium fluosilicate depress these minerals by preventing oleate species from reacting with $\mathrm{Ca}^{2+}$ or $\mathrm{Ba}^{2+}$ surface sites. Adsorption of tannin molecule in the valonea extract is the highest on the calcite surface, and sodium fluosilicate adsorption is the highest on the barite surface. 
Acknowledgments: This work was financially supported by "the Fundamental Research Funds for the Central Universities (WUT: 2016IVA048)".

Author Contributions: Zijie Ren, Futao Yu, Huimin Gao and Yongjun Peng conceived and designed the experiments; Futao Yu performed the experiments; Futao Yu and Zhijie Chen analysed the data; Lingyun Liu contributed analysis tools; Zijie Ren wrote the paper.

Conflicts of Interest: The authors declare no conflict of interest.

\section{References}

1. Tao, S.J.; Yu, F.T.; Gao, H.M.; Guan, J.F.; Hu, T.H.; Zheng, H.Y. Experimental research on beneficiation of typical fluorite ore in Wuling Mountain. Ind. Miner. Process. 2015, 6, 13-15.

2. Qian, Y.J.; Gao, L. Study on flotation separation for fluorite and salt minerals of calcite and barite. China Non-Met. Miner. Ind. 2014, 4, 18-21.

3. Takamori, T.; Tsunnekawa, M. Separation of calcite from fluorite ore by the adsorption-washing-flotation method. CIM 1982, 75, 80.

4. Schubert, H.; Baldauf, H.; Kramer, W.; Schoenherr, J. Further development of fluorite flotation form ores containing higher calcite contents with oleoylsarcosine as collector. Int. J. Miner. Process. 1990, 30, 185-193. [CrossRef]

5. Giesekke, E.W.; Harris, P.J. Study of the selective flotation of fluorite from calcite by the use of a single bubble-stream microflotation cell. Int. Conf. Miner. Sci. Technol. 1985, 1, 269-277.

6. Zhou, T.; Shi, W.H. Experimental research on the beneficiation of a high calcium fluorite mine in Jinta County. Met. Mine 2011, 3, 102-104.

7. Zhou, W.B.; Chen, J.; Feng, Q.; Song, S.X. The effect of acidized water glass on beneficiation test of Mexico high calcium type fluorite ore. Non-Met. Mines 2013, 36, 31-32.

8. Yin, W.Z.; Lu, Z.F.; Han, Y.X.; Li, Y.J. Application of NSOH in fluorite ore flotation and its depressing mechanism. J. Northeast. Univ. 2009, 30, 287-290.

9. Niu, Y.F.; Huang, M. Beneficiation production practice of carbonate-type fluorite ore in Qinglong. Conserv. Util. Miner. Res. 2010, 3, 16-19.

10. Lu, S.S.; Sun, C.Y. Effect of inorganic anion modifiers on flotability of barite in NaOl flotation system. Nonferr. Met. 2007, 4, 47-49.

11. Chen, B.; Zhou, X.S.; Li, Z.Z. Experimental study of flotation of fluorite ore. Yunnan Metall. 2004, 33, $14-17$.

12. Li, Y.; Deng, X.L.; Xu, S. Study on the adsorption properties of dextrin on barite and fluorite surface and interaction mechanism. J. Chin. Ceram. Soc. 1997, 25, 317-322.

13. Wang, S.Y.; Li, X.A.; Xue, W.Y. Mechanism of flotation separation of fluorite and barite with collector naphthenic acid and depressant aluminum sulfate. Non-Met. Mines 1997, 4, 39-41.

14. Gao, Z.Q. Study on the Complexation of Vanadium Ions with the Tannin Extract. Ph.D. Thesis, Taiyuan University of Technology, Taiyuan, China, 2013.

15. Hu, Y.H.; Gao, Z.Y.; Sun, W.; Liu, X.W. Anisotropic surface energies and adsorption behaviors of scheelite crystal. Colloids Surf. A Physicochem. Eng. Asp. 2012, 415, 439-448. [CrossRef]

16. Gocmez, H. The interaction of organic dispersant with alumina: A molecular modelling approach. Ceram. Int. 2006, 32, 521-525. [CrossRef]

17. Rai, B. Molecular modeling and rational design of flotation reagents. Int. J. Miner. Process. 2003, 72, 95-110.

18. Pradip, X.; Rai, B.; Rao, T.K.; Krishnamurthy, S.; Vetrivel, R.; Mielczarski, J.; Cases, J.M. Molecular modeling of interactions of diphosphonic acid based surfactants with calcium minerals. Langmuir 2002, 18, 932-940. [CrossRef]

19. Rai, B.; Sathish, P.; Tanwar, J.; Moon, K.S.; Fuerstenau, D.W. A molecular dynamics study of the interaction of oleate and dodecylammonium chloride surfactants with complex aluminosilicate minerals. J. Colloid Interface Sci. 2011, 362, 510-516. [CrossRef] [PubMed]

20. Xu, L.H.; Wu, H.Q.; Dong, F.Q.; Wang, L.; Wang, Z.; Xiao, J.H. Flotation and adsorption of mixed cationic/anionic collectors on muscovite mica. Miner. Eng. 2013, 41, 41-45. [CrossRef]

21. Fa, K.Q.; Jiang, T.; Nalaskowski, J.; Miller, J.D. Interaction forces between a calcium dioleate sphere and calcite/fluorite surface and their significance in flotation. Langmuir 2003, 19, 10523-10530. [CrossRef] 
22. Marinakis, K.I.; Shergold, H.L. Mechanism of fatty acid adsorption in the presence of fluorite, calcite and barite. Int. J. Miner. Process. 1985, 14, 161-176. [CrossRef]

23. Marinakis, K.I.; Shergold, H.L. Influence of sodium silicate addition on the adsorption of oleic acid by fluorite, calcite and barite. Int. J. Miner. Process. 1985, 14, 177-193. [CrossRef]

24. Yue, C.L. Research on the floatability of fluorite, barite and calcite. Ind. Min. Process. 2001, 9, 8-10.

25. Yu, B.Q. Research on the Flotation of Ultra-fine Rare Earth Mineral. Ph.D. Thesis, General Research Institute for Nonferrous Metals, Beijing, China, 2014.

26. Wang, C.X. The Flotation Theory and Application Study of the Alkaline Rock Type Rare Earth Ore. Ph.D. Thesis, Kunming University of Science and Technology, Kunming, China, 2013.

27. Ruan, W.; Wang, Y.T. The application of combined reagent in the flotation of PingShui tailings to recycle barite. China Min. Mag. 2009, 18, 224-227.

28. Yan, Y.; Zheng, G.S.; Zheng, S.L.; Hu, Z.B. Effects of depressant on recycling pyrite from tailings of lead-zinc ore. Ind. Min. Process. 2015, 1, 14-16.

29. Gao, L.K. The Distribution Floatation Flowsheet and Theoretic of Fine/Micro-Fine Rutile Ores. Ph.D. Thesis, Kunming University of Science and Technology, Kunming, China, 2009.

30. Zhang, C.H. The Experiment on Recycling of Iorn Minerals from Dahongshan Tailings. Ph.D. Thesis, Kunming University of Science and Technology, Kunming, China, 2011.

31. Song, N.P.; Zhang, Z.H.; Wu, Y.J.; Li, F.B. The methods of depressing phosphorus impurities in flotation process of molybdenum concentrate. Metal Mine 2009, 7, 183-184.

(C) 2017 by the authors; licensee MDPI, Basel, Switzerland. This article is an open access article distributed under the terms and conditions of the Creative Commons Attribution (CC BY) license (http:/ / creativecommons.org/licenses/by/4.0/). 